\title{
Labor markets, academic performance and school dropout risk: evidence for Spain
}

\author{
Juan Guio \\ University of Barcelona, Barcelona, Spain and Central University, Bogotá, Colombia \\ Álvaro Choi \\ Barcelona Institue of Education, University of Barcelona, Barcelona, Spain \\ Josep-Oriol Escardíbul \\ Barcelona Institue of Education, University of Barcelona, Barcelona, Spain
}

\section{Introduction}

Labor market dynamics and the expectations of finding a job are believed to be strong determinants of individuals’ educational decisions (see Belzil and Leonardi, 2007; Raaum and Røed, 2006). Indeed, labor market conditions can exercise two separate effects on schooling decisions. On the one hand, unemployment can increase the risk of school dropout and undermine academic performance via a first channel that we will refer to as the "family" effect of unemployment. Parental unemployment can lead to a deterioration in household conditions and in educational resources. In extreme cases, it may even compel young adults to complement the household income (Montmarquette et al., 2007). On the other hand, unemployment may have a positive influence on the individual demand for education via a "local labor market" effect. As labor opportunities worsen, the opportunity cost of education falls, and individuals are encouraged to stay in school (Albert, 2000).

Additionally, both types of unemployment effect ("family" and "local labor market") may be heterogeneous. For example, students from lower socio-economic groups might be more sensitive to labor market conditions (Ehrenberg and Brewer, 1994). At the same time, male students may be more responsive to changes in the labor market, particularly in societies where differences in gender stereotypes are accentuated.

The aim of this paper is to provide a better understanding of the links between labor market conditions and academic performance by disentangling the aforementioned effects of unemployment. The contribution of this study is, therefore, threefold: first, it provides new evidence on the link between labor market conditions and educational decisions; second, it quantifies separately the two possible effects of unemployment on academic performance at age 15: i) an increase in the risk of school dropout (family effect) and ii) an incentive for students to remain in school (local labor market effect); third, it analyses heterogeneous effects of the "family" and "local labor market" - proxied through the unemployment rate of the school community - effects.

We address these research questions by focusing on the case of Spain, which constitutes a particularly interesting case study. Spain has recently experienced a period of intense economic growth and development (1996-2007), during which the construction and service sectors boosted labor opportunities for young adults and low-skilled workers (Arranz and García-Serrano, 2012) - between 2000 and 2007, the general rate of unemployment fell from 10.6 to $8.3 \%$. This was followed by an economic downturn, so that by 2008 the adult unemployment rate had climbed back up to $11.3 \%$. Thereafter, the situation deteriorated rapidly and the general unemployment rate reached $24.8 \%$ in 2012. 
The early school dropout rate maintained a consistent trend at around 30\% from the end of the 1990s until 2008. Since 2000, this rate seems to have increased during periods of economic growth and to have fallen during periods of economic crisis (Figure 1). In the years between 2008 and 2012, the early school dropout rate recorded a marked shift falling from 38 to $28.8 \%$ for males, and from 25.7 to $20.8 \%$ for females (INE, 2015). Yet, in 2014, Spain still had the highest early school dropout rate in the European Union (21.9\%). In this regard, Figure 1 seems to point to the negative relationship between unemployment and school dropout rates as suggested by Lassibille and Navarro (2008).

[Insert Figure 1 around here]

Figure 1. Adult unemployment rate vs. early school leavers (18 to 24-year-olds)

Source: EUROSTAT and Spanish Labor Force Survey (EPA). Quarterly data.

We explore the "family" and "local labor market" effects of unemployment on the academic performance of Spanish students at age 15, using linear multilevel models applied to microdata from the OECD's Programme for International Student Assessment (PISA). Fifteen is a critical age in the Spanish education system, as compulsory education finishes at sixteen - also the legal working age. Given the fact that early school leaving decisions are usually the product of a cumulative process and tend to be preceded by a fall in academic performance (Barrington and Hendricks, 1989), focusing on 15-year-old students seems an appropriate choice for addressing our research questions for the Spanish case.

Our results show that: i) parental unemployment has, at most, a mild effect on academic performance; ii) the "school community" unemployment effect reduces performance, although this effect decreases as general unemployment rates rise; and iii) the "school community" unemployment effect is stronger for students with a low socio-economic profile.

The remainder of the paper is structured as follows: First, we briefly review the literature which assesses the relationship between labor market dynamics and individuals' schooling decisions. Next, we present the data and the methodology. We then turn to describe the results of the analyses. Finally, the main conclusions are presented in the last section. 


\section{Literature review}

Better educated workers have higher activity rates and face a lower risk of unemployment (Stern et al., 1989; Gautier, 2002). However, during economic crises, unemployment rates grow and the monetary returns to education might fall, affecting significantly the population with the lowest levels of formal instruction (Black et al., 2005). Therefore, schooling decisions may be closely related to changes in the labor market and their impact on the family and community. Indeed, Defloor et al. (2015) conclude that the quality of the first job depends considerably on individual effort, but that this effort depends largely on such circumstances as educational attainment and the situation of the labor market.

Several studies have provided evidence of the impact of changes in labor markets on academic performance and school dropout. Concerning the "family" effect of unemployment, family income may be a strong predictor of educational attainment (Carneiro and Heckman, 2002; Entwisle et al., 2005). Therefore, if the economic conditions of the household deteriorate, academic performance may be affected through a number of channels: firstly, via a reduction in the educational resources of the household (Strauss and Thomas, 1995) and the socioeconomic characteristics of the students (Rees and Mocan, 1997 and Maani and Kalb, 2007); secondly, via a deterioration in the household environment (Rumberger, 2011); and, thirdly, via the fact that a loss of household resources may prompt young adults to leave school and seek employment. Additionally, higher unemployment rates can be perceived as an indicator of negative future returns to the investment in education. Thus, an increase in the adult unemployment rate may increase the probability of future expected unemployment, which may in turn reduce the returns to education, and therefore discourage students from enrolling in secondary education (Micklewright, Pearson and Smith, 1990).

Concerning the "local labor market" effect of unemployment, Bickel (1989) and McNeal (1997) establish a negative relation between labor market conditions and early school dropout decisions. Rees and Mocan (1997) and Rivkin (1995) argue that there is a negative relationship between the general rate of unemployment and the proportion of high school students dropping out from school in any given year. Black, McKinnish and Sanders (2005) show that an increase in the demand for low-skilled workers may increase the opportunity costs of education, discouraging the acquisition of further schooling. This argument is similar to those defended by Aparicio (2010) and Malley and Muscatelli (1999). Finally, Duryea and Arends-Kuenning (2003), drawing on data from urban Brazilian students, found that an increase in local labor market opportunities made children more likely to leave school. 
Another major strand in the literature has been unable to detect significant evidence of a real impact of labor markets on individuals' schooling decisions. Manski and Wise (1983), drawing on data from the National Longitudinal Study of the Class of 1972 in the United States, found only weak evidence to support an interaction between local labor market opportunities and school permanency. In addition, Card and Lemieux (2001), exploring return to college trends in the United States, the United Kingdom and Canada, found that state level unemployment has no effect on educational attainment. Likewise, Warren and Lee (2003), using data from the 1988 National Educational Longitudinal Study and the 1990 United States Census, conclude that labor market conditions have no significant effect on high school dropout rates. Finally, Schady (2004) concludes that the macroeconomic crisis in Peru had no significant effect on students' school attendance rates, but found a significant increase in the mean educational attainment of those young adults affected by the crisis compared to those who were unaffected.

In the case of Spain, the effect of the relationship between the economic cycle and school dropout decisions has been investigated by Peraita and Pastor (2000) and Petrongolo and San Segundo (2002). These studies reveal an opposite relationship between the level of income, parental education and labor market conditions on the decision to drop out of school during primary and secondary education. Additionally, Aparicio (2010) explored the recent construction boom in Spain and its impact on school dropout rates via changes in labor conditions, concluding that this temporary shock affected more significantly the employment perspectives and educational decisions of low-educated males.

Finally, the relationship between gender and unemployment seems particularly marked in the case of women living in societies in which the expectation is for them to take on more traditional roles. In Spain, for example, there continues to be a high incidence of males in the traditional role of breadwinner (Cebrián and Moreno, 2013). As such, it is likely that the schooling decisions of males will be more sensitive to changes in the labor market.

\section{Methodological approach and data}

Our study draws on information from the 2006, 2009 and 2012 PISA waves, which allows us to monitor the academic performance of 15-year-old students both before and during the economic crisis. The analysis of the impact of unemployment on academic performance is undertaken using hierarchical linear regressions (HLR). 
The basic framework of the analysis is the education production function. The dependent variable is the student outcome (measured by PISA) as a function of the characteristics of the individuals, households and schools. The structure of the education production function is shown in equation (1), which considers HLR:

$$
y_{i j}=\gamma_{00}+\sum_{k=1}^{\rho} \beta_{k 0} X_{k i j}+u_{0 j}+\sum_{k=1}^{\rho} u_{k j} X_{k i j}+\xi_{i j}
$$

where $y_{i j}$ are the five plausible levels of the mathematical competencies of students participating in the respective PISA wave. We focus specifically on mathematical competencies as they are an important determinant of educational choices (Falch, Nyhus, and Strøm, 2014; Aughinbaugh, 2012). Ananat et al. (2011) suggest that in conditions of economic unrest and high unemployment, mathematics scores are most likely to fall. In the long run, mathematical competencies are closely linked to labor market outcomes (Checchi and Werfhorst, 2014; Joensen and Nielsen, 2009; McIntosh and Vignoles, 2001).

$X_{k i j}$ are a set of variables for individual $i$ enrolled at school $j ; u_{0 j}$ is the disturbance term at the individual level; $u_{k j}$ is the error term for the schools, measuring the deviation of each school from the mean slope; and finally $\xi_{i j}$ corresponds to a series of random or stochastic effects for the HLR model.

We monitored the evolution of the unemployment-related variables during the period under analysis using two strategies. First, a regression was estimated for each of the PISA waves considered (2006, 2009 and 2012). We then tracked the evolution in performance considering three periods: 2006-2009, 2006-2012 and, finally, 2009-2012. As such, we calculated trend indicators following the three-step method suggested by the OECD (2014). More specifically, we analyzed the evolution of the mathematical competencies for four subgroups. This exercise should provide deeper insights to both labor market effects.

Second, we estimated a pooled sample across the three waves in order to exploit the heterogeneity of the time-component variation. Both the individual and the grouped regressions are controlled by fixed effects, including dummies for each of the regions, and also year dummies in the case of the pooled regression.

In both strategies (i.e. the cross-sectional and pooled samples), the personal and household explanatory (level-1) variables included are the following: gender; an index of economic, social and cultural status (ESCS), and student origin (national students and first and second generation immigrant students). The independent variables related to school characteristics (level-2) are: the size of the community in which the school is located; type of school (publicly owned, privately owned, or concertado - privately owned but government dependent); the percentage of girls by school; the student-teacher ratio; the average ESCS by school; the ratio of immigrant 
students by school; the degree of autonomy regarding the school's budgetary allocation and in determining the school's curriculum content ${ }^{1}$.

We identify the "family" effect of unemployment as those households in which both parents are unemployed. Table 1 shows that when a student's father or mother is jobless, they are more likely to obtain a deficient result on the PISA test, and consequently are at a higher risk of abandoning the school system.

\section{[Insert Table 1]}

Identifying the "school community" unemployment effect with PISA is not straightforward. PISA data do not provide information on the students' place of residence ${ }^{2}$. Thus, we take an alternative approach. Two variables are incorporated in order to measure research question 2, namely, the "school community" unemployment effect: 1) the average labor status of the fathers by school, and 2) the average labor status of the mothers by school. These two variables measure the percentage of unemployed fathers and unemployed mothers at each school. These variables are expected to capture the reality of the labor market situation closest to the students, i.e. that related to their peers' families. This assumption can be made due to the characteristics of the Spanish system for allocating students. Students in Spain are typically allocated to public and concertado schools using what is known as the Boston mechanism (Calsamiglia and Güell, 2014).

The Boston mechanism assigns all applicants to their first-choice school, but in cases of oversubscription for a particular school, any ties have to be resolved. In the Spanish case, the criteria used to resolve all ties are primarily distance to the school from the student's home and/or parents' workplace. Applicants not accepted by their first-choice school can then opt for any free places in other schools, but only after everyone else's first choice has been honored. As such, the mechanism drastically reduces a student's chances of being accepted in a given school once they have been rejected by their first choice.

Given the system in operation, the vast majority of students are enrolled in schools that are close to their home or to their parents' workplace. Therefore, on average, the occupational status of the student's parents at each school provides an adequate proxy of the "school community" unemployment effect. However, we acknowledge that this variable is not fully exogenous - and, so, we cannot refer to it as a "local labor market" variable. Moreover, the system used in allocating students to schools also hampers identification of the "school

\footnotetext{
${ }^{1}$ Summary statistics of the explanatory variables are available upon request.

${ }^{2}$ PISA only provides information on the region (Comunidad Autónoma) and the size of the town/city/village where the school is located. Preliminary analyses linking regional unemployment rates from the Spanish Labour Force Survey were performed (results available upon request). However, unemployment rates may vary greatly within regions.
} 
community" unemployment effects: if geographical segregation reproduces socio-economic segregation, it may be harder to disentangle the effect of local labor markets from the socio-economic characteristics of people participating in those labor markets. We return to this issue in the results section.

To sum up, our models analyze two effects: the "family" and the "school community" unemployment effects on academic performance. Given that the labor market situation of a household is closely related to its socio-economic characteristics, the introduction of socio-economic characteristics is needed to disentangle the effects of labor market and socio-economic variables.

Finally, in order to address our third research question - the identification of heterogeneous effects - we incorporate an interaction between household unemployment and each of the quartiles of the ESCS index. Additionally, all the models are re-estimated for two subsamples: the top and bottom quartiles of ESCS.

\section{Empirical analysis}

Results for the HLRs of each wave and the pooled sample are presented in Table 3. Note that the coefficients should be interpreted as associations and not as causal effects. The model tested includes all first- and secondlevel explanatory variables, interactions between household unemployment and each of the quartiles of the ESCS index, and also two socio-economic and cultural index variables: household ESCS and average ESCS by school.

\section{[Insert Table 2]}

\subsection{Family effect}

When both parents are unemployed the academic performance of a student does not appear to worsen. However, when the interactions were excluded, the household unemployment effect was strongly significant in the 2006 regression. However, this effect became negligible as the number of unemployed households grew in later years. According to these results, the "family" effect of unemployment, which a priori was expected to have a strong influence on a student's decision to drop out of school and look for a job, does not seem to have a marked effect on a student's academic performance. However, the analyses by ESCS quartiles show that the "family" effect was very strong and statistically significant in 2006 - when unemployment rates were low. 


\subsection{School community unemployment effect.}

Contrary to expectations, the "school community" unemployment effect did not boost the academic performance of students. Attending a school in which a high proportion of the students' fathers are unemployed has a marked effect on their performance, serving, in fact, to reduce student achievement, albeit at a decreasing rate: by 73 points in 2006, 59 points in 2009, and 37 points in 2012. In the pooled sample, the effect of the percentage of unemployed fathers by school lowered student performance by 45 points. In contrast, the concentration of unemployed mothers by school was only significant in 2006, lowering the expected outcome in the students' mathematical competencies by 27 points. The "school community" unemployment effect, especially that of the local male unemployment rate, became less intense as the crisis deepened. At the same time, the "school community" effect has a clearly negative influence on the academic performance of students whose father is unemployed in all years, and this effect is even more statistically significant in the pooled sample regression.

The "school community" unemployment effect was expected to increase student performance, given that, as labor opportunities become scarcer, students have less motivation to drop out of school and look for work. However, the results do not reveal an increase in the expected outcomes of students as unemployment spreads, although a less negative effect on academic performance is recorded as the proportion of unemployed parents rises. Nevertheless, it should be noted that this decreasing rate might result from an inaccurate estimation, given that the number of schools with a large number of unemployed parents increases as a consequence of the generalized rise in unemployment.

The effect of the local female unemployment rate proxy is not as great as that of the male unemployment rate. This result suggests the persistence of traditional gender roles in Spanish households, where the mother's labor market decisions depend on the father's labor market situation.

Finally, it is not possible to rule out that the apparent lack of statistically significance of the "family" effect on the schooling decisions of young adults, may be in fact because the "school community" effect of unemployment is overcoming the "family" effect. Nevertheless, evidence in regard to this is inconclusive.

\subsection{Interactions by household unemployment and ESCS index quartiles.}

We modelled interactions between the "family" unemployment effect and each of the quartiles of the socioeconomic index distribution. In so doing, we expect to capture heterogeneous effects. As in the earlier analyses, we estimated the models with and without the ESCS index. We found no strong evidence in support of 
distinctive "family" effects on the students' academic performance by their socio-economic status. However, when testing the model interactions without the ESCS variables, we found the interactions between the lowest ESCS quartile and the "family" unemployment effect to be statistically significant, at least in the 2006 regression. But, as unemployment become a more generalized phenomenon in later years, the interactions ceased to be statistically significant.

Finally, we describe the students' performance trends on the mathematical competencies test by the following subgroups: i) the whole sample of students tested; ii) students with both parents unemployed; and, students with either the iii) father or iv) mother unemployed. Results are presented in Table 3.

\section{[Insert Table 3]}

These trends are estimated using a linear transformation that equalizes new and old data. The calculation of these trend indicators employs a three-step method: First, the difference between the mean estimates of unemployment obtained from the two pairs of tests are calculated; second, the standard error of the mean estimates is obtained; and, third, the standardized difference - i.e. the ratio of the difference between the means and the difference between the standard errors - is calculated. The methodology employed in calculating these trends is explained in detail in OECD (2014).

The overall performance in mathematics remained unchanged during the whole period. However, this result differs if we analyze the evolution in the performance of the different subgroups. For instance, between 2006 and 2009, there was a downturn in the performance of those students that had both parents out of work. However, the opposite is observed between 2009 and 2012. A possible explanation for this might be that, as labor opportunities deteriorated, the "family" effect of unemployment (which decreased between 2006 and 2009, and remained relatively constant between 2009 and 2012) was offset by the "school community" unemployment effect (which increased between 2006 and 2009 but decreased between 2009 and 2012). This result holds when we consider, first, changes in the performance of students whose fathers are unemployed and, second, changes in the performance of those whose mothers are out of work.

On the whole, these trends are consistent with our hypotheses. Between 2006 and 2009, we expected to observe a decrease in mathematics test scores due to the improvement in labor opportunities for young adults and, between 2009 and 2012, a positive change in the PISA results was anticipated as a consequence of the increase in the opportunity costs of studying. 
The above analyses have identified both the "family" and the "school community" unemployment effects, with the latter being statistically significant. Sensitivity analyses excluding ESCS-related variables ${ }^{3}$, however, highlight the close relationship between unemployment and socio-economic status. For instance, the interactions between household unemployment and the ESCS quartiles are statistically significant when the ESCS-related variables are excluded from the regressions. Thus, these results suggest that the effects of unemployment may not be homogeneous across the whole distribution of ESCS. In order to test this hypothesis, we split the sample into four sub-samples, by ESCS quartiles, and proceeded to replicate the models presented in Table 2, for each of these sub-samples. The results for the bottom and top ESCS quartiles are shown in Tables 4 and 5, respectively.

[Insert Table 4 around here]

[Insert Table 5 around here]

A common finding for both subsamples is that household unemployment only seems to have a negative effect on academic performance in 2006, with the coefficients being statistically non-significant in 2009 and 2012. However, the unemployment rate of students' fathers presents different effects depending on the SES-level of the students' households: on the one hand, the performance of students in the top quartile of the ESCS distribution seems to be independent of the unemployment level of their peers' fathers; while, on the other, the performance of students in the bottom quartile of the ESCS index is negatively affected by the level of unemployment of the school community. This pattern holds for the pooled model, as the magnitude of the effect of the unemployment rate of students' fathers for the lowest quartile of the ESCS index, almost doubles that for the highest ESCS quartile sample. Thus, the "school community" effect of unemployment appears to be biased towards the population with a low socio-economic, cultural and educational status. In addition, the household ESCS has a greater effect on the academic performance of low-SES students (Table 4) than on that of high-SES students (Table 5). A similar conclusion can be drawn for the schools' mean ESCS levels. These results highlight that low-SES students are more sensitive to the socio-economic environment.

As the crisis deepened and more families from different socio-economic backgrounds became jobless, the effect of unemployment on student performance waned. In short, the socio-economic level of the unemployed

\footnotetext{
${ }^{3}$ These analyses are available upon request.
} 
in 2012 had risen compared to that of their jobless counterparts in 2006. The analysis of the trends in this performance (Table 3) provides relevant supplementary evidence. Thus, there was a downturn in the performance of those students with one or both parents unemployed at the beginning of the crisis (2006 to 2009), lending weight to the idea of a strong initial “family" effect of unemployment on students' academic performance. Overall these results seem to confirm our first hypothesis.

Finally, certain limitations in our methodological approach could have been overcome if longitudinal data had been available. Nevertheless, this paper contributes to the existing literature by providing new evidence on the relationship between short-term labor market dynamics and academic performance. More specifically, this paper represents a significant step forward in comparison to the previous literature as it has provided responses to three key questions faced by countries with high unemployment and high early school dropout. To conclude, the deep economic crisis may have had a significant effect on the perceptions of young adults, encouraging a change in their expectations and social attitudes towards education. If this were in fact the case, then we can expect to observe a continuing decline in the early school dropout rate once the economic recovery begins. As such, this may be seen as a positive, long-run effect of the crisis. However, further research will be needed to answer this question.

\section{Discussion and conclusions}

The level of unemployment of the school community has a marked negative effect on the students' mathematical performance. This is an unexpected outcome in relation to our second research question. We report a negative effect on academic performance, but its magnitude had fallen by 2012. Indeed, the effect is only relevant in the case of the students' fathers and not in that of their mothers. We recognize that these results are not sufficiently compelling to claim that the "local labor market" effect of unemployment -proxied by the level of unemployment of the school community - generated an upturn in students' academic outcomes as the crisis become more intense. This effect is nevertheless not homogeneous across the ESCS distribution: while it is strong and statistically significant for students in the bottom ESCS quartile, it is statistically non-significant for those in the top quartile. It should be stressed that these same results were obtained even after controlling for the student- and school-levels of socioeconomic status, which points to the existence of an independent effect of the level of unemployment of the school community. 
As the crisis deepened (2009 to 2012), we observe a positive - or, at least, a non-negative - shift in student performance (Table 3). This can be partially explained by this greater reduction in the "school community unemployment" effects - compared to those attributable to the "family" effect - during the period 2009 to 2012. The results also suggest that the "school community unemployment" effects may offset the "family" effects, indicating that as the economic downturn intensified, the opportunity cost of education was lower and, therefore, students had a larger incentive to study and to remain at school. Yet, it is not possible to completely disentangle which part of the previous evolution was driven by the change in the social composition of the unemployed and which part was driven by the net effect of unemployment on the schooling decisions of young adults. Whether this trend continued beyond 2012 needs to be addressed in future research.

To conclude, our results show that academic performance at age 15 is affected by labor market conditions, and, at the same time, previous performance determines future educational decisions. Thus, these results highlight the sensitivity of students' educational decisions and academic performance to shifts in the labor market. This suggests that strategies aimed at reducing early school dropout rates should not be restricted solely to the education system. In other words, school failure is not only dependent on schools and, hence, on education policies. Moreover, as well as showing that the business cycle affects educational performance, this paper has also revealed the greater sensitivity of students from low socio-economic backgrounds to labor market conditions. An economic crisis, thus, represents an additional hazard to students from low socioeconomic backgrounds. The fact that early school dropout rates may be stemmed during economic crises - as has been reported in Spain (see Figure 1), due to a fall in the opportunity cost of schooling, does not mean that those students who opt to remain in education will perform well. Our results suggest the contrary: students whose parents are unemployed and that are enrolled in schools with a high incidence of unemployment tend to present a poor academic performance and, subsequently, face problems with regards to their future continuity in the educational system. This finding calls for the need to design targeted policies for students that present this profile, policies that should be more intensive during periods of economic crisis, and which eliminate deadends in the educational system so as to ease educational transitions. 


\section{References}

Albert, C. (2000), "Higher education demand in Spain: The influence of labour market signals and family background”, Higher Education, Vol. 40, No. 2, pp. 147-162.

Ananat, E., Gassman-Pines, A., Francis, D. and Gibson-Davis, C. (2011), “Children Left Behind: The Effects of Statewide Job Loss on Student Achievement”, NBER Working Paper No. 17104.

Aparicio, A. (2010), "High-school dropouts and transitory labor market shocks: The case of the Spanish housing boom”, Discussion Paper No. 5139, Bonn, IZA.

Arranz, J. and García-Serrano, C. (2012), "How green was my valley”. International Journal of Manpower, Vol. 35, No. 7, pp.1059-1087

Aughinbaugh, A. (2012) "The effects of high school math curriculum on college attendance: Evidence from the NLSY97”, Economics of Education Review, Vol. 31, No.6, pp. 861-870.

Barrington, B. and Hendricks, B. (1989), "Differentiating characteristics of high school graduates, dropouts and nongraduates”, Journal of Educational Research Vol.86, No.6, pp. 309-319.

Belzil, C. and Leonardi, M. (2007), “Can risk aversion explain schooling attainments? Evidence from Italy”, Labour Economics Vol.14, No.6, pp. 957-970.

Bickel, R. (1989), “Opportunity and High School Completion”, The Urban Review Vol.21, No.4, pp. 61-84.

Black, D., McKinnish, T. and Sanders, S. (2005), "The Economic Impact of the Coal Boom and Bust”, The Economic Journal Vol. 115, No.503, pp. 449-476.

Bushnik, T., Telford, L. B. and Bussière, P. (2004), "In and out of high school: First results from the second cycle of the Youth in Transition Survey, 2002", Statistics Canada Education, skills and learning research papers, 81-595-MIENo. 014.

Calsamiglia, C. and Güell, M. (2014), “The Illusion of School Choice: Empirical Evidence from Barcelona”. Discussion Paper No. 8202, Bonn, IZA.

Carabaña, J. (2004), “Educación y movilidad social”. In: Navarro, V. (coord.): El Estado de Bienestar en España. Cap. 8, pp. 209-237. Madrid: Tecnos-UPF.

Card, D. and Lemieux, T. (2001), "Can Falling Supply Explain The Rising Return To College For Younger Men? A Cohort-Based Analysis”, The Quarterly Journal of Economics Vol.116, No.2, pp. 705-746.

Carneiro, P. and Heckman, J. (2002), “The Evidence on Credit Constraints in Post-Secondary Schooling”, The Economic Journal, Vol.112, No.482, pp. 705-734.

Cebrián, I. and Moreno, G. (2013), "Labour Market Intermittency and its Effect on Gender Wage Gap in Spain”, Revue d'Interventions économiques, Vol. 47, pp. 2-19.

Checchi, D. and van de Werfhorst, H. G. (2014), "Educational Policies and Income Inequality”, Discussion Paper No. 8222, Bonn, IZA.

Defloor, B, Van Ootegem, L. and Verhofstadt, E. (2015), “A good or bad transition from school to work: who is responsible?” International Journal of Manpower, Vol. 36, Iss: 8, pp. 1207-1226

Duryea, S. and Arends-Kuenning, M. (2003), "School Attendance, Child Labor, and Local Labor Markets in Urban Brazil”, World Development, Vol.31, No.7, pp. 1165-1178.

Ehrenberg, R. and Brewer, D. (1994), "Did Teachers' Verbal Ability and Race Matter in the 1960s? Coleman revisited", Economics of Education Review Vol. 14, No.1, pp.1-21.

Entwisle, D. Alexander, K. and Olson, L. (2005), "First grade and educational attainment by age 22: a new story”, American Journal of Sociology, Vol.110, No. 5, pp.1458-1502.

Falch, T., Nyhus, O. H. and Strøm, B. (2014), “Causal effects of mathematics”, Labour Economics, Vol.31, pp.174-187.

Fernández, E., Mena, L. and Riviere, J. (2010), “School Failure and Dropouts in Spain”, Barcelona: Obra Social Fundación La Caixa. 
Fichbach, A., Keller, U., Preckel, F. and Brunner, M. (2013), "PISA proficiency scores predict educational outcomes”, Learning and Individual Differences Vol. 24, pp.63-72.

Gautier, P. (2002), "Unemployment and Search Externalities in a Model with Heterogeneous Jobs and Workers”, Economica, Vol. 69, No.273, pp. 21-40.

Hillman, K. and Thomson, K. (2006), "Pathways from PISA: LSAY and the 2003 PISA Sample Two Years On”, Melbourne: ACER.

Instituto Nacional de Estadística (INE) (2015), "Labor Force Survey (LFS) Education statistics. Level of education, training and permanent abandonment: Exploration of educational variables of labour force survey”, Available from: https://www.educacion.gob.es/educabase/menu.do?type=pcaxis\&path=/ Formacionyml/EPA2014/Indi\&file=pcaxis\&l=s0

Joensen, J. S. and Nielsen, H. S. (2009), "Is there a causal effect of high school math on labor market outcomes”, Journal of Human Resources, Vol. 44, No. 1, pp.171-98.

Lassibille, G. and Navarro Gómez, L. (2008), "Why do higher education students drop out? Evidence from Spain”, Education Economics Vol. 16, No.1, pp. 89-105.

Maani, S. and Kalb, G. (2007), "Academic performance, childhood economic resources, and the choice to leave school at age 16", Economics of Education Review, Vol. 26, No.3, pp. 361-374.

Manski, C. and Wise, D. (1983), College Choice in America, Cambridge, Mass: Harvard University Press.

Mahuteau, S. and Mavromaras, K. (2014), "An analysis of the impact of socio-economic disadvantage and school quality on the probability of school dropout”, Education Economics Vol. 22, No.4, pp. 389-411.

Malley, J. and Muscatelli, V. (1999), "Business cycles and productivity growth: Are temporary downturns productive or wasteful?”, Research in Economics, Vol. 53, No.4, pp. 337-364.

McIntosh, S. and Vignoles, A. (2001), "Measuring and Assessing the Impact of Basic Skills on Labour Market Outcomes", Oxford Economic Papers Vol. 53, No.3, pp. 453-481.

McNeal, R. (1997), "High school dropouts: A closer examination of school effects", Social Science Quarterly, Vol.78, No. 1, pp. 210-222.

Micklewright, J., Pearson, M. and Smith, S. (1990), “Unemployment and early school leaving”, The Economic Journal, Vol. 100, No.400, pp. 163-169.

Montmarquette, C., Viennot-Briot, N. and Dagenais, M. (2007), "Dropout, School Performance, and Working while in School”, The Review of Economics and Statistics, Vol. 89, No.4, pp. 752-760.

OECD (2014) PISA 2012 Technical Report, PISA. Paris: OECD.

OECD (2007) PISA 2006: Science competencies for tomorrow's world. Paris: OECD.

Peraita, C. and Pastor, M. (2000), "The primary school dropout in Spain: the influence of family background and labor market conditions”, Education Economics, Vol. 8, No.2, pp. 157-168.

Petrongolo, B. and San Segundo, M. J. (2002), "Staying-on at school at 16: the impact of labor market conditions in Spain”, Economics of Education Review, Vol. 21, No.4, pp. 353-365.

Raudenbush, S. and Bryk, A. (2002), Hierarchical Linear Models: Applications and Data Analysis Methods, Sage Publications, London, U.K.

Raaum, O. and Røed, K. (2006), "Do Business Cycle Conditions at the Time of Labor Market Entry Affect Future Employment Prospects?”, The Review of Economics and Statistics, Vol. 88, No.2, pp. 193-210.

Rees, D. I. and Mocan, H. N. (1997), "Labor market conditions and the high school dropout rate: Evidence from New York State", Economics of Education Review, Vol. 16, No.2, pp. 103-109.

Rivkin, M. (1995), The Great Outdoors: Restoring Children's Right to Play Outside, Washington, NAEYC Rumberger, R. W. (2011), Dropping Out, Harvard: Harvard University Press.

Stern, D., Paik, I. W., Catterall, J. S. and Nakata, Y. F. (1989), "Labor market experience of teenagers with and without high school diplomas”, Economics of Education Review, Vol. 8, No.3, pp. 233-246. 
Schady, N. R. (2004), “Do macroeconomic crises always slow human capital accumulation?”, World Bank Economic Review, Vol. 18, No. 2, pp. 131-153.

Schleicher, A. (2007), "Can competencies assessed by PISA be considered the fundamental school knowledge 15-year-olds should possess?”, Journal of Educational Change, Vol. 8, No.4, pp. 349-357.

Strauss, J. and Thomas, D. (1995), Human resources: Empirical modeling of household and family decisions, Handbook of Development Economics, Volume IIIA, edited by J. Behrman and T.N. Srinivasan. Amsterdam: Elsevier, pp.1883-2023.

Warren, J. R. and Lee, J. C. (2003), "The impact of adolescent employment on high school dropout: differences by individual and labor - market characteristics”, Social Science Research, Vol. 32, No. 1, pp. 98-128. 
Figure 1.

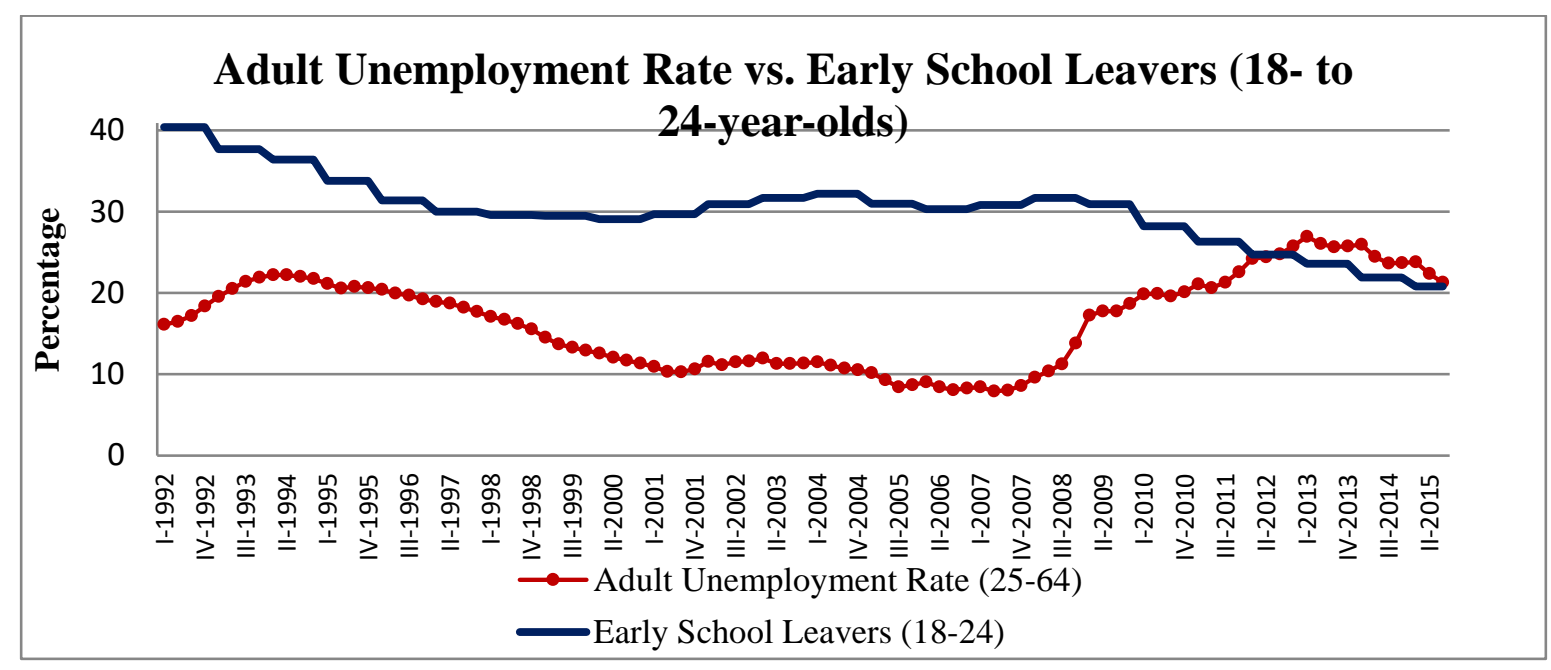


Table 1. Percentage of Spanish students under level-2 in the PISA mathematical competencies assessment, by parental labor status, 2006 to 2012.

\begin{tabular}{|c|c|c|c|}
\hline Personal and household variables & 2006 & 2009 & 2012 \\
\hline \multicolumn{4}{|l|}{ LABOR STATUS OF THE FATHER } \\
\hline Unemployed & $26.76 \%$ & $33.32 \%$ & $30.93 \%$ \\
\hline Occupied & $16.90 \%$ & $20.35 \%$ & $17.53 \%$ \\
\hline \multicolumn{4}{|l|}{ LABOR STATUS OF THE MOTHER } \\
\hline Unemployed & $21.95 \%$ & $28.29 \%$ & $24.28 \%$ \\
\hline Occupied & $15.76 \%$ & $18.60 \%$ & $17.65 \%$ \\
\hline \multicolumn{4}{|c|}{ HOUSEHOLD OCCUPATION STATUS } \\
\hline Both parents unemployed & $30.79 \%$ & $42.46 \%$ & $37.22 \%$ \\
\hline At least one parent working & $17.08 \%$ & $20.77 \%$ & $18.61 \%$ \\
\hline AGGREGATE MEAN & $17.31 \%$ & $21.84 \%$ & $19.73 \%$ \\
\hline
\end{tabular}

Source: Own compilation with OECD-PISA databases.

Note: Students below level 2 in PISA in mathematics are considered to face a higher risk of later failing to integrate successfully into the labour market and into society more generally. 
Table 2. Hierarchical Linear Regression: Effect of labor market, personal and school variables on mathematical competencies, 2006-2012 - Full sample

\begin{tabular}{|c|c|c|c|c|}
\hline & $\begin{array}{c}\text { PISA } 2006 \\
\text { Coeff. }\end{array}$ & $\begin{array}{c}\text { PISA } 2009 \\
\text { Coeff. }\end{array}$ & $\begin{array}{c}\text { PISA } 2012 \\
\text { Coeff. }\end{array}$ & $\begin{array}{l}\text { Pooled } \\
\text { Coeff. }\end{array}$ \\
\hline Intercept & $\begin{array}{c}489.964 \\
(1.49)\end{array}$ & $\begin{array}{c}477.522 \\
(1.54)\end{array}$ & $\begin{array}{c}482.674 \\
(1.26)\end{array}$ & $\begin{array}{c}491.562 \\
(0.79)\end{array}$ \\
\hline Household unemployment & $\begin{array}{l}-28.550 \\
(25.15)\end{array}$ & $\begin{array}{c}7.443 \\
(19.76)\end{array}$ & $\begin{array}{c}3.712 \\
(16.00)\end{array}$ & $\begin{array}{l}3.058 \\
(9.30)\end{array}$ \\
\hline Unemployment rate of the fathers in the school & $\begin{array}{c}-72.745^{* *} \\
(36.20)\end{array}$ & $\begin{array}{c}-59.157 * * \\
(22.02)\end{array}$ & $\begin{array}{c}-37.599 * * \\
(18.23)\end{array}$ & $\begin{array}{c}-44.824 * * * \\
(12.83)\end{array}$ \\
\hline Unemployment rate of the mothers in the school & $\begin{array}{c}-26.662^{* *} \\
(12.35)\end{array}$ & $\begin{array}{c}4.619 \\
(16.21)\end{array}$ & $\begin{array}{c}-1.553 \\
(11.45)\end{array}$ & $\begin{array}{l}-6.154 \\
(8.39)\end{array}$ \\
\hline Household unemployment* 4th ESCS quartile & $\begin{array}{c}-7.983 \\
(28.470)\end{array}$ & $\begin{array}{l}-10.875 \\
(21.11)\end{array}$ & $\begin{array}{l}-1.781 \\
(16.74)\end{array}$ & $\begin{array}{l}-8.213 \\
(9.98)\end{array}$ \\
\hline Household unemployment* 3rd ESCS quartile & $\begin{array}{c}4.443 \\
(33.09)\end{array}$ & $\begin{array}{l}-15.089 \\
(20.11)\end{array}$ & $\begin{array}{l}-12.769 \\
(16.25)\end{array}$ & $\begin{array}{l}-12.417 \\
(10.32)\end{array}$ \\
\hline Household unemployment* 2nd ESCS quartile & $\begin{array}{c}8.451 \\
(26.09)\end{array}$ & $\begin{array}{l}-22.501 \\
(18.31)\end{array}$ & $\begin{array}{l}-22.716 \\
(18.46)\end{array}$ & $\begin{array}{l}-19.608 \\
(11.61)\end{array}$ \\
\hline Gender & $\begin{array}{c}9.509 * * * \\
(1.80)\end{array}$ & $\begin{array}{c}19.667 * * * \\
(1.74)\end{array}$ & $\begin{array}{c}16.594 * * * \\
(1.64)\end{array}$ & $\begin{array}{c}14.606^{* * *} \\
(1.01)\end{array}$ \\
\hline ESCS Index & $\begin{array}{c}21.373^{* * * *} \\
(1.19)\end{array}$ & $\begin{array}{c}18.578^{* * *} \\
(1.02)\end{array}$ & $\begin{array}{c}11.731^{* * *} \\
(4.13)\end{array}$ & $\begin{array}{c}22.218^{* * *} \\
(0.61)\end{array}$ \\
\hline First generation immigrants & $\begin{array}{c}-34.702^{* * *} \\
(6.56)\end{array}$ & $\begin{array}{c}-41.309 * * * \\
(3.27)\end{array}$ & $\begin{array}{c}-32.110^{* * *} \\
(2.95)\end{array}$ & $\begin{array}{c}-37.988 * * * \\
(2.47)\end{array}$ \\
\hline Second generation immigrants & $\begin{array}{r}-0.110 \\
(5.26)\end{array}$ & $\begin{array}{l}-1.671 \\
(4.06)\end{array}$ & $\begin{array}{l}-1.834 \\
(3.40)\end{array}$ & $\begin{array}{l}-1.814 \\
(2.43)\end{array}$ \\
\hline Average ESCS by school & $\begin{array}{c}18.808^{* * *} \\
(4.44)\end{array}$ & $\begin{array}{c}13.615^{* * *} \\
(4.98)\end{array}$ & $\begin{array}{c}11.731^{* * *} \\
(4.13)\end{array}$ & $\begin{array}{c}14.167 * * * \\
(2.83)\end{array}$ \\
\hline Community (<100.000 inh.) & $\begin{array}{l}2.213 \\
(3.99)\end{array}$ & $\begin{array}{l}-6.784 \\
(4.35)\end{array}$ & $\begin{array}{l}2.020 \\
(2.89)\end{array}$ & $\begin{array}{l}-0.503 \\
(2.23)\end{array}$ \\
\hline Community (>1.000.000 inh.) & $\begin{array}{l}0.753 \\
(7.17)\end{array}$ & $\begin{array}{l}8.338 \\
(7.42)\end{array}$ & $\begin{array}{c}12.961^{* *} \\
(6.26)\end{array}$ & $\begin{array}{c}8.055^{*} \\
(4.16)\end{array}$ \\
\hline School private public dependent & $\begin{array}{l}-0.011 \\
(8.22)\end{array}$ & $\begin{array}{l}5.647 \\
(7.84)\end{array}$ & $\begin{array}{l}2.766 \\
(5.27)\end{array}$ & $\begin{array}{l}0.637 \\
(4.75)\end{array}$ \\
\hline School public & $\begin{array}{l}-0.551 \\
(9.50)\end{array}$ & $\begin{array}{l}0.972 \\
(8.16)\end{array}$ & $\begin{array}{l}-3.747 \\
(5.50)\end{array}$ & $\begin{array}{l}-1.635 \\
(5.06)\end{array}$ \\
\hline Percentage of females by school & $\begin{array}{l}3.922 \\
(3.04)\end{array}$ & $\begin{array}{l}0.637 \\
(3.67)\end{array}$ & $\begin{array}{l}1.153 \\
(3.17)\end{array}$ & $\begin{array}{c}3.854^{* * *} \\
(1.96)\end{array}$ \\
\hline Immigrant ration (over 30\%) & $\begin{array}{c}-27.556 * * \\
(11.96)\end{array}$ & $\begin{array}{l}-2.505 \\
(7.07)\end{array}$ & $\begin{array}{c}-21.543^{* * *} \\
(5.76)\end{array}$ & $\begin{array}{c}-16.919 * * * \\
(5.02)\end{array}$ \\
\hline Student/teacher ratio & $\begin{array}{l}2.301 \\
(5.71)\end{array}$ & $\begin{array}{l}-4.458 \\
(4.93)\end{array}$ & $\begin{array}{l}6.587^{*} \\
(3.45)\end{array}$ & $\begin{array}{l}3.052 \\
(2.73)\end{array}$ \\
\hline Autonomy on budget allocation & $\begin{array}{l}-5.514 \\
(16.89)\end{array}$ & $\begin{array}{l}-7.468 \\
(6.61)\end{array}$ & $\begin{array}{c}20.848^{* * *} \\
(5.36)\end{array}$ & $\begin{array}{l}5.772 \\
(6.45)\end{array}$ \\
\hline Autonomy on course content & $\begin{array}{l}3.158 \\
(3.35)\end{array}$ & $\begin{array}{l}6.547^{*} \\
(3.44)\end{array}$ & $\begin{array}{l}3.254 \\
(2.83)\end{array}$ & $\begin{array}{c}4.033^{* *} \\
(1.89)\end{array}$ \\
\hline 2009 year dummy & & & & $\begin{array}{c}7.574^{* * *} \\
(2.65)\end{array}$ \\
\hline 2012 year dummy & & & & $\begin{array}{c}9.792^{* * *} \\
(2.75)\end{array}$ \\
\hline Observations & 19,604 & 25,887 & 25,313 & 70,804 \\
\hline Number of schools & 686 & 889 & 902 & 2,477 \\
\hline
\end{tabular}

Standard error in parenthesis $\quad * * * p<0.01$

Source: Based on OECD-PISA databases. 
Note: The categories of reference are: Personal and household variables: being female; living in a household where at least one of the parents is working; being born in Spain. School variables: Schools with high incidence of employed fathers; Schools with high incidence of employed mothers; community where the school is located has more than 100,000 inhabitants and less than 1,000,000; privately owned schools; percentage of girls in the school; immigrant students ratio less than or equal to $29 \%$ of the school population; student-teacher ratio; school without autonomy on budget allocation and course content. The definitions of the variables included in the model are presented in Annex A. Goodness of fit measures presented in Annex B. 
Table 3. Trends in PISA mathematics performance before and after the economic downturn

\begin{tabular}{|c|c|c|c|c|c|c|c|c|}
\hline & Period & $\begin{array}{c}\text { Results } \\
\text { difference }\end{array}$ & $\begin{array}{r}\text { Statistically } \\
\text { significant }\end{array}$ & $\begin{array}{l}\text { Link } \\
\text { error }\end{array}$ & $\begin{array}{c}\text { Link } \\
\text { Covariance }\end{array}$ & $\begin{array}{c}\begin{array}{c}\text { Standard } \\
\text { error }\end{array} \\
\end{array}$ & $\begin{array}{c}\text { Standardized } \\
\text { difference }\end{array}$ & $\begin{array}{l}\text { Hypotheses } \\
\text { testing }\end{array}$ \\
\hline \multirow{3}{*}{$\begin{array}{l}\text { Change in the } \\
\text { performance of } \\
\text { the students }\end{array}$} & 2006-2009 & 3 & No & 1.333 & & 3.39 & 0.89 & FALSE \\
\hline & 2006-2012 & 4 & No & 2.084 & & 3.64 & 1.10 & FALSE \\
\hline & 2009-2012 & -2 & No & & -0.064 & 5.33 & 0.37 & FALSE \\
\hline \multirow{3}{*}{$\begin{array}{l}\text { Change in the performance } \\
\text { of students with both } \\
\text { parents unemployed }\end{array}$} & 2006-2009 & -19 & Yes & 1.333 & & 6.15 & -3.09 & TRUE (-) \\
\hline & 2006-2012 & -13 & Yes & 2.084 & & 6.09 & -2.13 & TRUE (-) \\
\hline & 2009-2012 & 25 & Yes & & -0.064 & 8.72 & 2.87 & TRUE (+) \\
\hline \multirow{3}{*}{$\begin{array}{l}\text { Change in the performance } \\
\text { of students with only father } \\
\text { unemployed }\end{array}$} & 2006-2009 & -11 & Yes & 1.333 & & 3.91 & -2.82 & TRUE (-) \\
\hline & $2006-2012$ & -9 & Yes & 2.084 & & 4.10 & -2.19 & TRUE (-) \\
\hline & 2009-2012 & 13 & Yes & & -0.064 & 5.71 & 2.28 & TRUE (+) \\
\hline \multirow{3}{*}{$\begin{array}{l}\text { Change in the performance } \\
\text { of students with only } \\
\text { mother unemployed }\end{array}$} & 2006-2009 & -13 & Yes & 1.333 & & 2.05 & -6.33 & TRUE (-) \\
\hline & $2006-2012$ & -5 & No & 2.084 & & 2.60 & -1.92 & FALSE \\
\hline & 2009-2012 & 21 & Yes & & -0.064 & 3.69 & 5.69 & TRUE (+) \\
\hline
\end{tabular}

Source: Own calculations based on OECD (2014) and PISA databases. 
Table 4. Hierarchical Linear Regression: Effect of labor market, personal and school variables on mathematical competencies, 2006-2012 - ESCS bottom quartile

\begin{tabular}{|c|c|c|c|c|}
\hline & $\begin{array}{c}\text { PISA } 2006 \\
\text { Coeff. }\end{array}$ & $\begin{array}{c}\text { PISA } 2009 \\
\text { Coeff. }\end{array}$ & $\begin{array}{c}\text { PISA } 2012 \\
\text { Coeff. }\end{array}$ & $\begin{array}{l}\text { Pooled } \\
\text { Coeff. }\end{array}$ \\
\hline Intercept & $\begin{array}{c}464.041 \\
(2.20)\end{array}$ & $\begin{array}{c}457.008 \\
(1.89)\end{array}$ & $\begin{array}{c}457.046 \\
(1.67)\end{array}$ & $\begin{array}{c}459.250 \\
(1.25)\end{array}$ \\
\hline Household unemployment & $\begin{array}{c}-84.818^{* * *} \\
(21.43)\end{array}$ & $\begin{array}{l}-13.192 \\
(12.06)\end{array}$ & $\begin{array}{c}9.330 \\
(12.29)\end{array}$ & $\begin{array}{c}-10.143 \\
(9.68)\end{array}$ \\
\hline Unemployment rate of the fathers in the school & $\begin{array}{c}-129.602 * * * \\
(47.82)\end{array}$ & $\begin{array}{c}-90.057 * * * \\
(30.55)\end{array}$ & $\begin{array}{c}-74.766^{* * *} \\
(26.32)\end{array}$ & $\begin{array}{c}-74.876^{* * *} \\
(18.63)\end{array}$ \\
\hline Unemployment rate of the mothers in the school & $\begin{array}{l}-17.314 \\
(17.89)\end{array}$ & $\begin{array}{l}32.994 \\
(21.64)\end{array}$ & $\begin{array}{c}2.080 \\
(16.75)\end{array}$ & $\begin{array}{c}6.537 \\
(11.67)\end{array}$ \\
\hline Household unemployment* 4th ESCS quartile & $\begin{array}{c}73.722^{* *} \\
(24.25)\end{array}$ & $\begin{array}{c}9.372 \\
(15.63)\end{array}$ & $\begin{array}{l}-12.521 \\
(14.93)\end{array}$ & $\begin{array}{c}7.399 \\
(10.90)\end{array}$ \\
\hline Household unemployment*3rd ESCS quartile & $\begin{array}{c}69.554^{* *} \\
(31.49)\end{array}$ & $\begin{array}{l}16.385 \\
(15.06)\end{array}$ & $\begin{array}{c}0.667 \\
(15.40)\end{array}$ & $\begin{array}{l}16.995 \\
(11.76)\end{array}$ \\
\hline Household unemployment* 2nd ESCS quartile & $\begin{array}{l}28.185 \\
(40.08)\end{array}$ & $\begin{array}{c}8.298 \\
(19.01)\end{array}$ & $\begin{array}{l}-6.376 \\
(14.68)\end{array}$ & $\begin{array}{c}0.906 \\
(13.22)\end{array}$ \\
\hline Gender & $\begin{array}{c}10.121^{* *} \\
(3.88)\end{array}$ & $\begin{array}{c}22.718^{* * *} \\
(3.24)\end{array}$ & $\begin{array}{c}14.379 * * * \\
(2.98)\end{array}$ & $\begin{array}{c}15.760 * * * \\
(2.02)\end{array}$ \\
\hline ESCS Index & $\begin{array}{c}45.607 * * * \\
(4.93)\end{array}$ & $\begin{array}{c}33.606^{* * *} \\
(4.19)\end{array}$ & $\begin{array}{c}27.371^{* * *} \\
(4.23)\end{array}$ & $\begin{array}{c}35.798^{* * *} \\
(2.70)\end{array}$ \\
\hline First generation immigrants & $\begin{array}{c}-38.655^{* * *} \\
(10.12)\end{array}$ & $\begin{array}{c}-45.725^{* * *} \\
(5.26)\end{array}$ & $\begin{array}{c}-30.378 * * * \\
(4.77)\end{array}$ & $\begin{array}{c}-39.085^{* * *} \\
(3.72)\end{array}$ \\
\hline Second generation immigrants & $\begin{array}{l}-3.927 \\
(9.90)\end{array}$ & $\begin{array}{l}6.694 \\
(7.86)\end{array}$ & $\begin{array}{l}-7.090 \\
(7.57)\end{array}$ & $\begin{array}{l}-2.229 \\
(4.88)\end{array}$ \\
\hline Average ESCS by school & $\begin{array}{c}13.114^{*} \\
(6.75)\end{array}$ & $\begin{array}{c}20.456^{* * *} \\
(7.29)\end{array}$ & $\begin{array}{l}5.105 \\
(6.23)\end{array}$ & $\begin{array}{c}13.405^{* * *} \\
(4.36)\end{array}$ \\
\hline Community (<100.000 inh.) & $\begin{array}{l}0.815 \\
(5.37)\end{array}$ & $\begin{array}{l}2.680 \\
(6.03)\end{array}$ & $\begin{array}{l}1.687 \\
(4.15)\end{array}$ & $\begin{array}{l}3.351 \\
(3.09)\end{array}$ \\
\hline Community (>1.000.000 inh.) & $\begin{array}{l}-5.357 \\
(16.42)\end{array}$ & $\begin{array}{l}17.067 \\
(14.08)\end{array}$ & $\begin{array}{l}12.730 \\
(12.56)\end{array}$ & $\begin{array}{l}9.237 \\
(8.26)\end{array}$ \\
\hline School private public dependent & $\begin{array}{l}-18.625 \\
(19.62)\end{array}$ & $\begin{array}{l}15.711 \\
(12.79)\end{array}$ & $\begin{array}{l}-3.147 \\
(10.32)\end{array}$ & $\begin{array}{l}-0.493 \\
(11.60)\end{array}$ \\
\hline School public & $\begin{array}{c}1.025 \\
(21.66)\end{array}$ & $\begin{array}{l}11.185 \\
(12.63)\end{array}$ & $\begin{array}{l}-10.238 \\
(10.94)\end{array}$ & $\begin{array}{c}0.263 \\
(11.85)\end{array}$ \\
\hline Percentage of females by school & $\begin{array}{l}-1.783 \\
(3.90)\end{array}$ & $\begin{array}{l}-2.347 \\
(4.82)\end{array}$ & $\begin{array}{l}4.578 \\
(4.81)\end{array}$ & $\begin{array}{l}0.757 \\
(2.83)\end{array}$ \\
\hline Immigrant ration (over 30\%) & $\begin{array}{l}-25.213 \\
(16.16)\end{array}$ & $\begin{array}{c}2.480 \\
(10.87)\end{array}$ & $\begin{array}{c}-24.818^{* * *} \\
(8.68)\end{array}$ & $\begin{array}{c}-13.981^{* *} \\
(6.76)\end{array}$ \\
\hline Student/teacher ratio & $\begin{array}{c}22.473^{* *} \\
(10.66)\end{array}$ & $\begin{array}{l}-2.561 \\
(5.98)\end{array}$ & $\begin{array}{l}3.312 \\
(5.49)\end{array}$ & $\begin{array}{l}6.930 \\
(4.31)\end{array}$ \\
\hline Autonomy on budget allocation & $\begin{array}{l}10.845 \\
(24.90)\end{array}$ & $\begin{array}{l}-2.586 \\
(8.81)\end{array}$ & $\begin{array}{c}22.526^{* *} \\
(10.64)\end{array}$ & $\begin{array}{c}8.814 \\
(10.25)\end{array}$ \\
\hline Autonomy on course content & $\begin{array}{c}10.359 * * \\
(5.00)\end{array}$ & $\begin{array}{c}10.239 * * \\
(5.04)\end{array}$ & $\begin{array}{l}1.924 \\
(4.31)\end{array}$ & $\begin{array}{c}7.529 * * * \\
(2.82)\end{array}$ \\
\hline 2009 year dummy & & & & $\begin{array}{c}11.895^{* * *} \\
(4.07)\end{array}$ \\
\hline 2012 year dummy & & & & $\begin{array}{c}12.662 * * \\
(4.75)\end{array}$ \\
\hline Observations & 4,901 & 6,499 & 6,324 & 17,724 \\
\hline Number of schools & 641 & 834 & 846 & 2,321 \\
\hline
\end{tabular}

Standard error in parenthesis $\quad * * * p<0.01 \quad{ }^{* *} p<0.05 \quad{ }^{*} p<0.1$

Source: Based on OECD-PISA databases.

Note: Categories of reference defined in Table 2. The definitions of the variables included in the model are presented in Annex A. Goodness of fit measures presented in Annex C. 
Table 5. Hierarchical Linear Regression: Effect of labor market, personal and school variables on mathematical competencies, 2006-2012- ESCS top quartile

\begin{tabular}{|c|c|c|c|c|}
\hline & $\begin{array}{c}\text { PISA } 2006 \\
\text { Coeff. }\end{array}$ & $\begin{array}{c}\text { PISA } 2009 \\
\text { Coeff. }\end{array}$ & $\begin{array}{c}\text { PISA } 2012 \\
\text { Coeff. }\end{array}$ & $\begin{array}{l}\text { Pooled } \\
\text { Coeff. }\end{array}$ \\
\hline Intercept & $\begin{array}{c}528.277 \\
(2.06)\end{array}$ & $\begin{array}{c}525.494 \\
(1.99)\end{array}$ & $\begin{array}{c}526.460 \\
(1.88)\end{array}$ & $\begin{array}{c}527.154 \\
(1,29)\end{array}$ \\
\hline Household unemployment & $\begin{array}{c}-61.795 * * \\
(20.53)\end{array}$ & $\begin{array}{l}-19.942 \\
(42.89)\end{array}$ & $\begin{array}{l}36.125 \\
(27.46)\end{array}$ & $\begin{array}{c}0.016 \\
(37.73)\end{array}$ \\
\hline Unemployment rate of the fathers in the school & $\begin{array}{c}-106.006^{*} \\
(58.17)\end{array}$ & $\begin{array}{l}-50.490 \\
(42.80)\end{array}$ & $\begin{array}{c}-3.842 \\
(39.05)\end{array}$ & $\begin{array}{l}-35.483 \\
(23.16)\end{array}$ \\
\hline Unemployment rate of the mothers in the school & $\begin{array}{l}-23.168 \\
(22.88)\end{array}$ & $\begin{array}{l}-5.507 \\
(22.56)\end{array}$ & $\begin{array}{l}-24.780 \\
(25.91)\end{array}$ & $\begin{array}{l}-16.794 \\
(14.17)\end{array}$ \\
\hline Household unemployment* 4th ESCS quartile & $\begin{array}{c}94.662 * * \\
(39.53)\end{array}$ & $\begin{array}{l}14.155 \\
(43.14)\end{array}$ & $\begin{array}{l}-41.932 \\
(34.67)\end{array}$ & $\begin{array}{c}1.901 \\
(38.21)\end{array}$ \\
\hline Household unemployment* 3rd ESCS quartile & $\begin{array}{l}-3.834 \\
(38.50)\end{array}$ & $\begin{array}{l}46.870 \\
(40.39)\end{array}$ & $\begin{array}{c}-74.636^{* *} \\
(31.13)\end{array}$ & $\begin{array}{l}-13.766 \\
(36.14)\end{array}$ \\
\hline Household unemployment* 2nd ESCS quartile & $\begin{array}{c}78.438^{* *} \\
(28.43)\end{array}$ & $\begin{array}{l}34.888 \\
(35.26)\end{array}$ & $\begin{array}{l}-22.350 \\
(40.29)\end{array}$ & $\begin{array}{l}21.148 \\
(39.89)\end{array}$ \\
\hline Gender & $\begin{array}{c}17.926 * * * \\
(4.05)\end{array}$ & $\begin{array}{c}14.285^{* * *} \\
(3.08)\end{array}$ & $\begin{array}{c}18.812^{* * * *} \\
(3.45)\end{array}$ & $\begin{array}{c}17.122^{* * *} \\
(2.03)\end{array}$ \\
\hline ESCS Index & $\begin{array}{c}15.437 * * * \\
(5.50)\end{array}$ & $\begin{array}{c}21.092^{* * *} \\
(4.33)\end{array}$ & $\begin{array}{c}11.728 * \\
(5.57)\end{array}$ & $\begin{array}{c}15.994 * * * \\
(2.89)\end{array}$ \\
\hline First generation immigrants & $\begin{array}{l}-12.382 \\
(14.62)\end{array}$ & $\begin{array}{c}-29.250 * * \\
(9.86)\end{array}$ & $\begin{array}{c}-37.574 * * * \\
(9.33)\end{array}$ & $\begin{array}{c}-26.618^{* * *} \\
(7.00)\end{array}$ \\
\hline Second generation immigrants & $\begin{array}{l}6.030 \\
(8.65)\end{array}$ & $\begin{array}{l}-3.979 \\
(8.41)\end{array}$ & $\begin{array}{r}-6.532 \\
(5.35)\end{array}$ & $\begin{array}{r}-1.395 \\
(4.34)\end{array}$ \\
\hline Average ESCS by school & $\begin{array}{c}21.082 * * * \\
(6.85)\end{array}$ & $\begin{array}{l}8.351 \\
(7.81)\end{array}$ & $\begin{array}{l}13.784 \\
(8.22)\end{array}$ & $\begin{array}{c}12.990 * * * \\
(4.46)\end{array}$ \\
\hline Community (<100.000 inh.) & $\begin{array}{l}2.317 \\
(5.90)\end{array}$ & $\begin{array}{c}-14.050^{*} \\
(6.92)\end{array}$ & $\begin{array}{l}-2.437 \\
(4.45)\end{array}$ & $\begin{array}{l}-4.128 \\
(3.42)\end{array}$ \\
\hline Community (>1.000.000 inh.) & $\begin{array}{l}6.967 \\
(9.68)\end{array}$ & $\begin{array}{l}3.617 \\
(9.99)\end{array}$ & $\begin{array}{l}11.059 \\
(8.67)\end{array}$ & $\begin{array}{l}6.797 \\
(5.55)\end{array}$ \\
\hline School private public dependent & $\begin{array}{l}3.969 \\
(8.94)\end{array}$ & $\begin{array}{l}-3.853 \\
(9.13)\end{array}$ & $\begin{array}{l}6.401 \\
(7.73)\end{array}$ & $\begin{array}{l}1.240 \\
(4.96)\end{array}$ \\
\hline School public & $\begin{array}{c}2.171 \\
(10.77)\end{array}$ & $\begin{array}{l}-2.685 \\
(9.96)\end{array}$ & $\begin{array}{l}2.904 \\
(7.80)\end{array}$ & $\begin{array}{l}0.623 \\
(5.78)\end{array}$ \\
\hline Percentage of females by school & $\begin{array}{c}11.597^{* *} \\
(5.13)\end{array}$ & $\begin{array}{l}4.233 \\
(5.70)\end{array}$ & $\begin{array}{l}-0.376 \\
(4.89)\end{array}$ & $\begin{array}{l}5.691 * \\
(3.04)\end{array}$ \\
\hline Immigrant ration (over 30\%) & $\begin{array}{l}-22.985 \\
(21.47)\end{array}$ & $\begin{array}{c}7.470 \\
(10.92)\end{array}$ & $\begin{array}{c}-22.610^{*} \\
(10.80)\end{array}$ & $\begin{array}{c}-11.364 \\
(8.60)\end{array}$ \\
\hline Student/teacher ratio & $\begin{array}{l}-4.110 \\
(8.93)\end{array}$ & $\begin{array}{l}-1.198 \\
(8.00)\end{array}$ & $\begin{array}{c}11.408^{* *} \\
(5.38)\end{array}$ & $\begin{array}{l}3.749 \\
(4.25)\end{array}$ \\
\hline Autonomy on budget allocation & $\begin{array}{c}4.401 \\
(14.61)\end{array}$ & $\begin{array}{l}-8.961 \\
(9.81)\end{array}$ & $\begin{array}{c}24.242^{* * *} \\
(8.48)\end{array}$ & $\begin{array}{l}8.409 \\
(6.45)\end{array}$ \\
\hline Autonomy on course content & $\begin{array}{l}-5.635 \\
(4.67)\end{array}$ & $\begin{array}{c}12.664^{* *} \\
(6.00)\end{array}$ & $\begin{array}{l}2.643 \\
(4.49)\end{array}$ & $\begin{array}{l}3.791 \\
(3.03)\end{array}$ \\
\hline 2009 year dummy & & & & $\begin{array}{c}9.089^{* *} \\
(4.20)\end{array}$ \\
\hline 2012 year dummy & & & & $\begin{array}{c}12.410^{* * *} \\
(4.14)\end{array}$ \\
\hline Observations & 4,898 & 6,471 & 6,316 & 17,685 \\
\hline Number of schools & 640 & 845 & 844 & 2,329 \\
\hline
\end{tabular}

Standard error in parenthesis $\quad * * * p<0.01 \quad{ }^{* *} p<0.05 \quad * p<0.1$

Source: Based on OECD-PISA databases.

Note: Categories of reference defined in Table 2. The definitions of the variables included in the model are presented in Annex A. Goodness of fit measures presented in Annex D. 
Annex A Variable description

\begin{tabular}{|c|c|}
\hline Variable & Description \\
\hline Gender & Dummy variable identifying females \\
\hline Household unemployment & Dummy variable identifying if both parents are unemployed \\
\hline First generation immigrants & $\begin{array}{l}\text { Dummy variable identifying if student and parents are born } \\
\text { outside of Spain }\end{array}$ \\
\hline Second generation immigrants & $\begin{array}{l}\text { Dummy variable identifying if student was born in Spain but } \\
\text { parents are born outside of Spain }\end{array}$ \\
\hline ESCS index & $\begin{array}{l}\text { Index of economic, social and cultural status. This index is a } \\
\text { composed index that combines the highest occupational status and } \\
\text { highest educational level of parents, family wealth, cultural } \\
\text { possessions and home educational resources. The index takes a } \\
\text { zero value for the average OECD student, the standard deviation } \\
\text { across equally weighted OECD countries being one. Positive } \\
\text { values describe a higher ESCS level. }\end{array}$ \\
\hline Unemployment rate of the fathers in the school & $\begin{array}{l}\text { Ratio of unemployed fathers / total number of fathers in the } \\
\text { school. }\end{array}$ \\
\hline Unemployment rate of the mothers in the school & $\begin{array}{l}\text { Ratio of unemployed mothers / total number of mothers in the } \\
\text { school. }\end{array}$ \\
\hline Average ESCS by school & Average of ESCS index by school \\
\hline Community (<100.000 inh.) & $\begin{array}{l}\text { Dummy variable identifying if the community where the school is } \\
\text { located has less than } 100,000 \text { inhabitants }\end{array}$ \\
\hline Community (>1.000.000 inh.) & $\begin{array}{l}\text { Identifies if the community where the school is located has more } \\
\text { than } 1,000,000 \text { inhabitants }\end{array}$ \\
\hline School private public dependent & Private schools financed with public resources \\
\hline School public & Public schools \\
\hline Percentage of females by school & Percentage of females over the school population \\
\hline Immigrant ratio (over $30 \%$ ) & $\begin{array}{l}\text { Schools were the concentration of immigrants is over } 30 \% \text { of the } \\
\text { school population }\end{array}$ \\
\hline Student/teacher ratio & $\begin{array}{l}\text { Number of students divided by the number of teachers on a given } \\
\text { grade by school }\end{array}$ \\
\hline Autonomy on budget allocation & $\begin{array}{l}\text { If the school has the authority and responsibility to decide the } \\
\text { management allocation of the funds }\end{array}$ \\
\hline Autonomy of course content & $\begin{array}{l}\text { If the school has the authority and responsibility to decide the } \\
\text { curriculum and instructional assessment. }\end{array}$ \\
\hline Household unemployment* 4th ESCS quartile & $\begin{array}{l}\text { Interaction between household unemployment and the } 4^{\text {th }} \\
\text { quartiles of the ESCS index. }\end{array}$ \\
\hline Household unemployment* 3rd ESCS quartile & $\begin{array}{l}\text { Interaction between household unemployment and the } 3^{\text {rd }} \\
\text { quartiles of the ESCS index. }\end{array}$ \\
\hline Household unemployment* 2nd ESCS quartile & $\begin{array}{l}\text { Interaction between household unemployment and the } 2^{\text {nd }} \\
\text { quartiles of the ESCS index. }\end{array}$ \\
\hline
\end{tabular}

Source: Own elaboration. 
Annex B. Variance reduction analysis results for the models displayed in Table 2

\begin{tabular}{|c|c|c|c|c|c|c|c|}
\hline & $\begin{array}{l}\text { Intra class } \\
\text { correlation }\end{array}$ & $\begin{array}{c}\text { Reliability } \\
\text { range }\end{array}$ & Chi-square & P-value & $\begin{array}{c}\text { Within school } \\
\text { variance }\end{array}$ & $\begin{array}{c}\text { Between school } \\
\text { variance }\end{array}$ & $\begin{array}{c}\text { Total explained } \\
\text { variance }\end{array}$ \\
\hline Null model & 0.201 & 0.865 & $6,201.95$ & 0.00 & & & \\
\hline Full model & 0.073 & 0.673 & 2,635.96 & 0.00 & 0.073 & 0.710 & 0.202 \\
\hline \multicolumn{8}{|l|}{2009 model } \\
\hline & $\begin{array}{l}\text { Intra class } \\
\text { correlation }\end{array}$ & $\begin{array}{c}\text { Reliability } \\
\text { range }\end{array}$ & Chi-square & P-value & $\begin{array}{c}\text { Within school } \\
\text { variance }\end{array}$ & $\begin{array}{c}\text { Between school } \\
\text { variance }\end{array}$ & $\begin{array}{c}\text { Total explained } \\
\text { variance }\end{array}$ \\
\hline Null model & 0.208 & 0.869 & $9,441.14$ & 0.00 & & & \\
\hline Full model & 0.118 & 0.774 & $4,607.03$ & 0.00 & 0.100 & 0.542 & 0.192 \\
\hline \multicolumn{8}{|l|}{2012 model } \\
\hline & $\begin{array}{l}\text { Intra class } \\
\text { correlation }\end{array}$ & $\begin{array}{c}\text { Reliability } \\
\text { range }\end{array}$ & Chi-square & P-value & $\begin{array}{l}\text { Within school } \\
\text { variance }\end{array}$ & $\begin{array}{c}\text { Between school } \\
\text { variance }\end{array}$ & $\begin{array}{c}\text { Total explained } \\
\text { variance }\end{array}$ \\
\hline Null model & 0.207 & 0.861 & $7,547.02$ & 0.00 & & & \\
\hline Full model & 0.083 & 0.692 & $3,328.00$ & 0.00 & 0.097 & 0.687 & 0.219 \\
\hline \multicolumn{8}{|c|}{ Pooled model } \\
\hline & $\begin{array}{l}\text { Intra class } \\
\text { correlation }\end{array}$ & $\begin{array}{c}\text { Reliability } \\
\text { range }\end{array}$ & Chi-square & P-value & $\begin{array}{l}\text { Within school } \\
\text { variance }\end{array}$ & $\begin{array}{l}\text { Between school } \\
\text { variance }\end{array}$ & $\begin{array}{c}\text { Total explained } \\
\text { variance }\end{array}$ \\
\hline Null model & 0.209 & 0.868 & $23,456.97$ & 0.00 & & & \\
\hline Full model & 0.097 & 0.732 & $11,138.21$ & 0.00 & 0.091 & 0.632 & 0.204 \\
\hline
\end{tabular}

Note: The table reports the difference between the variance component for the unconditional model with random intercept (one-way ANOVA) and the full model. It also reports information about the outcome variability of within-group and between-group variance. The significant difference in the variance between groups in the all estimations justifies the use of linear hierarchical models. 
Annex C. Variance reduction analysis results for the models displayed in Table 4

\begin{tabular}{|c|c|c|c|c|c|c|c|}
\hline & $\begin{array}{l}\text { Intra class } \\
\text { correlation }\end{array}$ & $\begin{array}{c}\text { Reliability } \\
\text { range }\end{array}$ & Chi-square & P-value & $\begin{array}{l}\text { Within school } \\
\text { variance }\end{array}$ & $\begin{array}{c}\text { Between school } \\
\text { variance }\end{array}$ & $\begin{array}{c}\text { Total explained } \\
\text { variance }\end{array}$ \\
\hline Null model & 0.107 & 0.459 & $1,231.42$ & 0.00 & & & \\
\hline Full model & 0.047 & 0.273 & 884.61 & 0.00 & 0.084 & 0.628 & 0.142 \\
\hline \multicolumn{8}{|l|}{2009 model } \\
\hline & $\begin{array}{l}\text { Intra class } \\
\text { correlation }\end{array}$ & $\begin{array}{c}\text { Reliability } \\
\text { range }\end{array}$ & Chi-square & P-value & $\begin{array}{c}\text { Within school } \\
\text { variance }\end{array}$ & $\begin{array}{c}\text { Between school } \\
\text { variance }\end{array}$ & $\begin{array}{c}\text { Total explained } \\
\text { variance }\end{array}$ \\
\hline Null model & 0.143 & 0.512 & $2,486.10$ & 0.00 & & & \\
\hline Full model & 0.101 & 0.427 & $1,751.94$ & 0.00 & 0.081 & 0.377 & 0.123 \\
\hline \multicolumn{8}{|l|}{2012 model } \\
\hline & $\begin{array}{l}\text { Intra class } \\
\text { correlation }\end{array}$ & $\begin{array}{c}\text { Reliability } \\
\text { range }\end{array}$ & Chi-square & P-value & $\begin{array}{c}\text { Within school } \\
\text { variance }\end{array}$ & $\begin{array}{c}\text { Between school } \\
\text { variance }\end{array}$ & $\begin{array}{c}\text { Total explained } \\
\text { variance }\end{array}$ \\
\hline Null model & 0.133 & 0.490 & $2,099.85$ & 0.00 & & & \\
\hline Full model & 0.069 & 0.333 & $1,491.82$ & 0.00 & 0.046 & 0.543 & 0.113 \\
\hline \multicolumn{8}{|c|}{ Pooled model } \\
\hline & $\begin{array}{l}\text { Intra class } \\
\text { correlation }\end{array}$ & $\begin{array}{c}\text { Reliability } \\
\text { range }\end{array}$ & Chi-square & P-value & $\begin{array}{c}\text { Within school } \\
\text { variance }\end{array}$ & $\begin{array}{c}\text { Between school } \\
\text { variance }\end{array}$ & $\begin{array}{c}\text { Total explained } \\
\text { variance }\end{array}$ \\
\hline Null model & 0.129 & 0.490 & $5,720.09$ & 0.00 & & & \\
\hline Full model & 0.081 & 0.378 & $4,259.82$ & 0.00 & 0.067 & 0.442 & 0.115 \\
\hline
\end{tabular}

Note: The table reports the difference between the variance component for the unconditional model with random intercept (one-way ANOVA) and the full model. It also reports information about the outcome variability of within-group and between-group variance. The significant difference in the variance between groups in the all estimations justifies the use of linear hierarchical models. 
Annex D. Variance reduction analysis results for the models displayed in Table 5

\begin{tabular}{|c|c|c|c|c|c|c|c|}
\hline & $\begin{array}{l}\text { Intra class } \\
\text { correlation }\end{array}$ & $\begin{array}{c}\text { Reliability } \\
\text { range }\end{array}$ & Chi-square & P-value & $\begin{array}{c}\text { Within school } \\
\text { variance }\end{array}$ & $\begin{array}{l}\text { Between school } \\
\text { variance }\end{array}$ & $\begin{array}{c}\text { Total explained } \\
\text { variance }\end{array}$ \\
\hline Null model & 0.171 & 0.503 & $1,979.39$ & 0.00 & & & \\
\hline Full model & 0.101 & 0.378 & $1,349.43$ & 0.00 & 0.015 & 0.460 & 0.091 \\
\hline \multicolumn{8}{|l|}{2009 model } \\
\hline & $\begin{array}{l}\text { Intra class } \\
\text { correlation }\end{array}$ & $\begin{array}{c}\text { Reliability } \\
\text { range }\end{array}$ & Chi-square & P-value & $\begin{array}{l}\text { Within school } \\
\text { variance }\end{array}$ & $\begin{array}{c}\text { Between school } \\
\text { variance }\end{array}$ & $\begin{array}{c}\text { Total explained } \\
\text { variance }\end{array}$ \\
\hline Null model & 0.215 & 0.560 & $2,832.27$ & 0.00 & & & \\
\hline Full model & 0.167 & 0.495 & $2,062.03$ & 0.00 & 0.021 & 0.281 & 0.077 \\
\hline \multicolumn{8}{|l|}{2012 model } \\
\hline & $\begin{array}{l}\text { Intra class } \\
\text { correlation }\end{array}$ & $\begin{array}{c}\text { Reliability } \\
\text { range }\end{array}$ & Chi-square & P-value & $\begin{array}{l}\text { Within school } \\
\text { variance }\end{array}$ & $\begin{array}{c}\text { Between school } \\
\text { variance }\end{array}$ & $\begin{array}{c}\text { Total explained } \\
\text { variance }\end{array}$ \\
\hline Null model & 0.184 & 0.524 & $2,356.74$ & 0.00 & & & \\
\hline Full model & 0.167 & 0.495 & $1,839.40$ & 0.00 & 0.030 & 0.431 & 0.104 \\
\hline \multicolumn{8}{|c|}{ Pooled model } \\
\hline & $\begin{array}{l}\text { Intra class } \\
\text { correlation }\end{array}$ & $\begin{array}{c}\text { Reliability } \\
\text { range }\end{array}$ & Chi-square & P-value & $\begin{array}{l}\text { Within school } \\
\text { variance }\end{array}$ & $\begin{array}{l}\text { Between school } \\
\text { variance }\end{array}$ & $\begin{array}{c}\text { Total explained } \\
\text { variance }\end{array}$ \\
\hline Null model & 0.188 & 0.526 & $7,058.26$ & 0.00 & & & \\
\hline Full model & 0.135 & 0.442 & $5,360.78$ & 0.00 & 0.020 & 0.343 & 0.081 \\
\hline
\end{tabular}

Note: The table reports the difference between the variance component for the unconditional model with random intercept (one-way ANOVA) and the full model. It also reports information about the outcome variability of within-group and between-group variance. The significant difference in the variance between groups in the all estimations justifies the use of linear hierarchical models. 
